\title{
BEBAN KERJA PELAYANAN REKAM MEDIS DI MASA PADEMI COVID-19
}

\author{
Yul Asriati, S.Psi., M.P.H \\ Prodi Rekam Medis \& Informasi Kesehatan FKM Universitas Veteran Bangun Nusantara \\ Email: yulasriati66@gmail.com
}

\begin{abstract}
ABTRACT
The outpatient registration officer is the first part the patient meets when he goes to the health service. Where the medical record service fills in information about patient data. The purpose of this study was to determine services in the medical record unit during the Covid-19 pandemic, to see the workload of medical record officers at the Muhammadiyah Selogiri Hospital health service during the covid-19 period. Using qualitative methods with 3 informants, namely the head of the medical record room, the registration section, the filling section, the assembling section, the result is that the Selogiri hospital in the Pademi period has gone digital using telemedicine and registration through the website and WhatsApp, besides the hospital Muhammadiyah Selogiri already has a policy of using SIM Hospital utility review in carrying out the information obtained to make it easier for claims to the BPJS. Conclusion Muhammdiayah Selogiri Hospital has headed for digitization, starting to use the telemedicine application and the website and whasapp in its registration.
\end{abstract}

Keywords: medical records, outpatient care, medical record services during the covid-19 period

\begin{abstract}
ABSTRAK
Petugas bagian pendaftaran rawat jalan merupakan bagian pertama yang di temui pasien saat ke pelayananan kesehan. Dimana pelayanan rekam medis tersebut mengisi informasi - informasi mengenai data pasien. Tujuan penelitian ini adalah untuk mengetahui pelayanan di unit rekam medis di masa pademi covid-19, melihat beban kerja petugas rekam medis di pelayanan kesehatan Rumah Sakit Muhammadiyah Selogiri di masa pademi covid-19. Menggunakan metode kualitatif dengan informan berjumlah 3 orang informan yaitu kepala ruang rekam medis, bagian pendaftaran, bagian filling, bagian assembling, Hasilnya di ketahui bawah rumah sakit selogiri di masa pademi sudah menuju digitalisasi menggunakan telemedicine dan pendaftaran melalui website dan whasapp, selain itu rumah sakit Muhammadiyah Selogiri sudah memliki kebijakan memakai memakai SIM RS utillity review dalam menjalankan informasi yang diperoleh agar memudahkan dalam klaim ke BPJS. Kesimpulan Rumah Sakit Muhammdiayah Selogiri sudah menuju digitalisasi mulai menggunakan aplikasi telemedicine dan website serta whasapp dalam pendaftaranya.
\end{abstract}

Kata kunci: rekam medis, rawat jalan, pelayanan rekam medis dimasa covid-19 


\section{PENDAHULUAN}

Coronavirus adalah penyakit jenis baru yang ditemukan menyebabkan penyakit covid-19 sedangkan Covid-19 adalah penyakit menular yang disebabkan oleh jenis Coronavirus yang baru ditemukan. Virus baru dan penyakit yang disebabkan ini tidak dikenal sebelum mulainya wabah di Wuhan, Tiongkok, bulan Desmber 2019. Covid-19 ini sekarang menjawab sebuah pandemic yang terjadi di banyak Negara di seluru dunia.

Di Indonesia data kasus covid-19 per tanggal 13 Juni 2020 di ketahui bahwa kasus kematian 2.091 (CFR: 5,6\%) dan meningkat setiap harinya Jurnal Hospital Infection dan WHO menyatakan tingginya angka risiko terhadap tenaga kesehatan disebabkan, antara lain, oleh faktor lama terpapar dan jumlah paparan virus. Salah satunya lantaran banyak tenaga kesehatan yang tak menyadari bahwa yang mereka tangani mengidap corona.

Seperti diketahui bahwa rumah sakit merupakan garda terdepan rujukan dari pelayanan kesehatan lainnya sehingga dalam pelaksanaanya harus ada kemudahan, dimana kemudahan itu berawal saat keluarga pasien mencari parkiran mobil mereka, mencari bagian pendaftaran pasien dan kelancaran system antrean, disusul keramahan dan kecepatan petugas di tempat pendaftaran, kenyamanan ruang tunggu, keramahan dan kecepatan pelaynanan (Muninjaya. 2015)

Pelayanan pertama saat pasien memasuki rumah sakit adalah pelayanan di rekam medis, pelayanan yang ada di Unit layanan rekam medis, meliputi : TPPRJ, TPPRI, TPPGD, URJ, URI, UGD, assembling, koding dang indeksing, filing serta analising dan reporting.

Tempat pendaftaran rawat jalan merupakan gerbang pertama dalam pasien memulai pelayanan di rumah sakit sehingga antrian yang banyak ada dibagian pendaftaran rawat jalan.

Rumah Sakit Muhammadiyah Selogiri merupakan salah satu rumah sakit yang menerima pasien covid-19. Berdasarkan studi pendahuluan di ketahui bahwa saat Pademi Rumah Sakit Muhammadiyah Selogiri menerima pasien covid-19 yang baru dikeathui positif setelah melakukan pelayanan di Rumah Sakit Muhammadiyah Selogiri. Berdasarkan uraian latar belakang diatas, maka rumusan masalah dalam penelitian ini adalah "Bagaimanakah beban kerja petugas rekam medis pendaftaran rawat jalan masa Pademi covid-19 Di Pelayanan Kesehatan Rumah Sakit Muhammadiyah Selogiri.

\section{METODE}

\section{Jenis dan Desain Penelitian}

Penelitian ini merupakan penelitian dengan menggunakan pendekatan kualitatif. Penelitian Kualitatif adalah penelitian yang berlandaskan pada filsafat postpositivisme, digunakan untuk meneliti pada kondisi alamiah, dimana peniliti adalah sebagai instrumen kunci, teknik pengumpulan data dilakukan secara triangulasi, analisis data bersifat induktif dan hasil penelitian kualitatif menekankan makna dari pada generalisasi (Creswell, 2012).

Tujuan kualitatif penelitian ini untuk menemukan hasil penelitian Menemukan, menginterprestasi, dan merivisi fakta-fakta (Creswell, 2012). Metode atau kerangka pikir yang digunakan peneliti dalam menganalisis menggunakan triangulasi data

Penelitian dilakukan Pendaftaran rawat jalan pendaftaran TPPRJ, bagian assembling, koding/indeksing, analising/ reporting dan dokumen rekam medis di Rumah Sakit Muhammadiyah Selogiri. 
Penelitian dilakukan pada bulan September 2020.

Data dikumpulkan melalui observasi, telaah dokumentasi dan wawancara kepada petugas terkait. Teknik pengambilan sampel dokumen diambil menggunakan purposive sampling, yaitu pengambilan sampel penelitian berdasarkan pertimbangan kriteria informan yang di anggap berkaitan dengan penelitian.

Instrumen Penelitian yaitu Pedoman Wawancara Mendalam, Pedoman Observasi, Pedoman Studi Dokumentasi, Lembar Kesediaan Responden (Informed Consent), Alat tulis, Kamera dan Recorder

\section{HASIL}

\section{Jumlah Petugas Rumah Sakit Muhammadiyah Selogiri}

\begin{tabular}{|l|l|l|}
\hline No & Bagian & Jumlah \\
\hline 1 & Kepala UKRM & 1 Orang \\
\hline 2 & Pelaksana & 13 Orang \\
\hline
\end{tabular}

Pasien yang mendaftar Rawat Jalan Masa Pademi covid-19 ada penurunan di awal masa pandemi covid-19 pada awal bulan maret setelah itu ada peningkatan pasien di bulan Juni ini terjadi karena takut tertularnya penyakit covid-19 dari pasien yang datang ke rumah sakit.

Dalam implemntasinya selama masa pademi covid-19 ini Rumah Sakit Muhammadiyah Selogiri sudah mengarah ke digitalisasi di mana pendaftaran sudah bisa via online. Rumah Sakit Muhammadiyah selogiri sudah menggunakan Website, telemedicine, dan grub whatsapp yang di sediakan sehingga pasien yang ingin mendaftar bisa reservasi di hari sebelum kedatangan dan mengurangi antrian panjang yang ada di rumah sakit, selain itu pasien bisa melihat langsung melalui website jadwal - jadwal praktek dokter dokter spesialis yang standby di rumah sakit.

Pada awal pademi ada pengurangan jam masuk kerja serta tidak dilakukanya lembur karena akan menambah beban kerja dan dapat mengurangi imun tubuh petugas. Sehingga pasien - pasien yang mendaftar di hari sebelumnya berkasnya sudah dipersiapkan pada pasien mendaftar sehingga saat pasien datang berkas sudah tersedia. Ini untuk membantu petugas rekam medis selanjutnya di rawat jalan pada hari selanjutnya. Untuk pasien pasein yang akan melakukan rapid dan swap dilakukan jam tunggu berkas dan diberikan secara online apabila data yang diperoleh positif maka tidak ada kontak lanjutan dengan pasien tersebut.

Pasien yang datang langsung ke rumah sakit tetap dilayani dengan tetap diarahkan mendaftar lewat online sehingga tidak ada penumpukan yang signifikan di bagian pendaftaran rawat jalan.

Menajemen data di rumah sakit sudah menggunakan System Informasi Manajemen Rumah Sakit (SIM RS), sehingga pasien yang datang sudah masuk ke system informasi manajemen rumah sakit dan sudah bias di lihat oleh petugas petugas kesehatan di poliklinik maupun di bagian lainya untuk memperlancar data pasien yang berada selama di rumah sakit. hal ini dilakukan agar petugas tidak terbebani, atau menambah atau menumpuk pekerjaan di hari sebelum dan saat pelayanan berlangsung. Untuk kepentingan verifikasi data BPJS, berkas tidak di sampaikan ke BPJS langsung sebagai upaya agar tidak ada kontak dengan rumah sakit, tetapi menggunakan verifikasi dengan utility review yang ada SIM RS.

Bagi pasien yang tidak berkenan datang ke rumah sakit muhammadiya selogiri bisa berkonsultasi via telemedice 


\begin{abstract}
sehingga mempermuda dalam pelayanannya.Selain itu ada penambahan petugas sebanyak 2 orang di bulan Juli 2020 untuk membantu pelaksanaan rekam medis kesehatan elektronik (RKE) yang akan di lakukan pada tahun depan.
\end{abstract}

\section{PEMBAHASAN}

Usia kematian pasien COVID-19 bukan saja terjadi pada lansia tetapi juga pada usia lebih kurang 25 tahun termasuk pada tenaga medis maupun kesehatan di Rumah Sakit.

Berdasarkan pasal 57 undang undang tenaga kesehatan menyebutkan bahwa tenaga kesehatan dalam menjalankan prakteknya berhak.

1. Memperoleh perlindungan hukum sepanjang melaksankaan tugas sesuai dengan standar, standar pelayanan profesi, dan standar prsoedur operasional

2. Memperoleh informasi yang lengkap dan benar dari penerima pelayanan kesehatan atau keluarganya

3. Menerima imbalan jasa

4. Memperoleh perlindungan atas keselamatan dan kesehatan kerja, perlakuan yang sesuai dengan harkat dan martabab manusia, moral, kesusilaan serta nilai - nilai agama

5. Mendapatkan kesempatan untuk mengembangkan profesinya

6. Menolak keinginan penerima pelayanan kesehtaan atau pihak lain yang bertentangan dengan satnadar profesi, kode etik, standar pelayanan, standar prosedur operasional atau ketentuan peraturan perundangundangan dan Memperoleh hak lain sesuai ketentuan peraturan perundang - undangan.

Unit rekam medis rawat jalan merupakan garda terdepan yang di kunjungi oleh pasien, dimana saat pasien datang ke rumah sakit tempat yang pertama ditujuh merupakan bagian pendaftaran.

Dalam menciptakan kondisi optimal bagi pekerja dapat dilakukan dengan salah satu cara yaitu mengurangi beban kerja. Beban kerja dapat diminimalkan dengan membagi pekerjaan, menyediakan alat yang dapat mempercepat pekerjaan, atau dengan menambah jumlah tenaga kerja (Rianti \& Mahawati.2015) dalam hal ini rumah sakit muhammadiyah selogiri sudah menambah jumlah tenaga rekam medis dan menyediakan aplikasi digital guna menunjang membludaknya pasien yang datang langsung ke rumah sakit.

Untuk menghindari akumulasi dari kelelahan yang terlalu berlebihan, diperlukan adanya keseimbangan antara masukan sumber datangnya kelelahan dengan jumlah keluaran yang diperoleh lewat proses pemulihan (recovery). Proses pemulihan akan memberikan kesempatan kerja fisik maupun psikologis (mental) manusia untuk lepas dari beban kerja yang menghimpitnya. Dengan pengaturan jadwal istirahat yang lebih sering daripada dengan jadwal istirahat yang jarang akan memberikan total produktivitas rata - rata yang lebih konstan Suma'mur (dalam Rianti \& Mahawati. 2015).

Penelitian dari Hariyono (2009) bahwa beban kerja mempunyai hubungan yang signifikan dengan kelelahan kerja. Apabila beban kerja berlebih akan berpengaruh dengan kinerjanya, dimana hal ini berkaitan dengan tingkat kelelahan atau kejenuhan seseorang. Hal ini akan berdampak pada penurunan kualitas pelayanan. Selain itu adanya hubungan beban kerja di tempat kerja dengan kelelahan kerja, artinya semakin berat beban kerja di tempat kerja maka semakin tinggi tingkat kelelahan kerja. Penelitian tersebut menyimpulkan bahwa kelelahan kerja adalah faktor utama penyebab stres 
kerja, namun terdapat juga faktor lain sebagai penyebab stres kerja, yaitu faktor tempat bekerja, jenis pekerjaan serta beban mental (Kasmarani. 2012).

Menurut Warndani (2018) Beban kerja untuk pelaksana rekam medis shift pagi tergolong normal meskipun berdasarkan pencatatan pada daily log dan konfi rmasi melalui wawancara terdapat beberapa hari dimana terjadi penambahan kegiatan kerja. Hal tersebut terjadi ketika terdapat kenaikan jumlah pasien yang umumnya terjadi di hari-hari tertentu seperti pada hari senin hingga kamis, adanya berkas rekam medis yang tidak lengkap, permintaan data oleh manajemen ataupun unit terkait dan terkadang masih terdapat operan dari shift sebelumnya yang pekerjaannya dilimpahkan ke pelaksana shift pagi. Namun, kegiatan tersebut tidak terjadi secara periodik sehingga tidak terjadi peningkatan beban kerja yang signifi kan. Beban kerja normal merupakan beban kerja dimana karyawan dan pekerjaan yang dilakukan seimbang sehingga tidak mengalami kesulitan dalam melaksanakan pekerjaannya (Ajitia \& Prasetya, 2017).

\section{SIMPULAN}

Rumah Sakit Muhammadiyah Selogiri Wonogiri sudah menuju digitalisasi dengan menerapkan pendaftaran via online melalui web, whasapp dan telemedicine. Pendaftaran via online pada satu hari sebelumnya langsung di siapkan berkasnya pada hari itu juga untuk pelayanan hari besoknya sehingga tidak terjadi penumpukan berkas rekam medis pasien.

\section{DAFTAR PUSTAKA}

Ajitia, M. \& Prasetya, A. 2017. Efektivitas Manpower Planning dengan
Menggunakan Metode Analisis Beban Kerja (Workload Analysis) Berdasarkan Pendekatan Full Time Equivalent. Jurnal Administrasi Bisnis (JAB), Volume 42, pp. 27-35.

Budi, S.C. 2011. Manajemen Unit Kerja Rekam Medis. Yogyakarta: Quantum Sinergis Media.

Creswell, John W. 2012. Research Design Pendekatan Kualitatif,. Kuantitatif, dan Mixed. Yogyakarta: Pustaka Pelajar

Hariyono, et all. 2009. Hubungan antara beban kerja, stress kerja, dan tingkat konflik dengan kelelahan kerja perawat di rumah sakit islam Yogyakarta PDHI. Jurnal kesmas UAD. 3 (3): 186-197

Hatta, Gemala R. 2013. Pedoman Manajemen Informasi Kesehatan Disarana Pelayanan Kesehatan (Revisi 2). Jakarta: Universitas Indonesia.

Kasmarani, M.K. 2012. Pengaruh beban kerja fisik dan mental terhadap stres kerja pada perawat di instalasi gawat darurat (IGD) RSUD Cianjur. Jurnal Kesehatan Masyarakat. I (3): 767-776

Rianti, Lavenia \& Mahawati, Eni. 2015. analisis beban kerja berdasarkan metode WISN pertugas assembling di RSUD Tugurejo Semarang

Wardanis,Dwi Trisana. 2018. Analisis beban kerja tenaga rekam medis rumah sakit bedah 
Jurnal Manajemen Informasi dan Administrasi Kesehatan (JMIAK)

ISSN: 2621-6612 | Email: jmiakmedrec@gmail.com

Volume 03 Nomor 02 November 2020 Halaman 44-49

Surabaya menggunakan metode

FTE. Jurnal Administrasi kesehatan indonesia. Vol 6 no 1.

, 2006. Departemen kesehatan. Jakarta

https://www.who.int/indonesia/ news/novel-coronavirus/qa-forpublic

,2020.

https://covid19.kemkes.go.id/\#

,2020.https://www.journalo

fhospitalinfection.com/article/S0195-

$\underline{6701(20) 30101-8 / \text { fulltext }}$ 